\title{
METHODOLOGY FOR ANALYSING PESTICIDE MULTI- RESIDUE IN WUYI ROCK TEA USING MODIFIED QUECHERS FOLLOWED BY GAS CHROMATOGRAPHY-TANDEM MASS SPECTROMETRY
}

\author{
XU, Z. Y. ${ }^{1}-$ XIAO, X. ${ }^{2}-$ JIANG, X. B. ${ }^{1}-$ CAI, P. M. ${ }^{1,3,4^{*}}$ \\ ${ }^{1}$ College of Tea and Food Science, Wuyi University, Wuyishan 354300, China \\ ${ }^{2}$ Wuyishan Food Hygiene Supervision and Inspection Center, Wuyishan 354300, China \\ ${ }^{3}$ Biological Control Research Institute, College of Plant Protection, Fujian Agriculture and \\ Forestry University Fuzhou 350002, China
}

${ }^{4}$ Key Laboratory of Biopesticide and Chemical Biology, Ministry of Education, Fuzhou 350002, China

*Corresponding author

e-mail: caipumo@qq.com; telephone number: +86-150-8045-6908

(Received $4^{\text {th }}$ Dec 2020; accepted $8^{\text {th }}$ Feb 2021)

\begin{abstract}
Tea is one of the most commonly consumed drinks worldwide, the production of which often uses a variety of multi-class pesticides. Development of a reliable method to determine the presence and quantity of any pesticide residue is therefore highly important. In the present study, we developed a validated method for the analysis of 33 pesticides in Wuyi Rock tea using the QuEChERS sample preparation method and capillary gas chromatography-tandem mass spectrometry (GC-MS/MS). After extracting the target components from the tea matrix using acetonitrile, a mixture of adsorbents [primary secondary amine (PSA; $400 \mathrm{mg}$ ), graphite carbon black (GCB; $400 \mathrm{mg}$ ), octadecylsilane (C18; $100 \mathrm{mg})]$ and salting-out solvents [anhydrous $\mathrm{NaCl}(1 \mathrm{~g})$ and $\mathrm{MgSO}_{4}(4 \mathrm{~g})$ ] were used for clean-up, and an analyte protectant solution [sorbitol $(10 \mathrm{mg} / \mathrm{mL})$ and L-gulonic acid- $\gamma$-lactone $(20 \mathrm{mg} / \mathrm{mL})$ ] was added. For accurate quantification, a matrix-matched calibration method was applied. For all pesticides at concentration levels of $20-500 \mathrm{ng} / \mathrm{ml}$, good linear calibrations with coefficients of $\left(R^{2}\right) \geq 0.994$ were acquired. The recovery values of samples spiked with 20,100 , and $400 \mathrm{ng} / \mathrm{kg}$ doses of analytes ranged from 72.3 to $110.6 \%$, and the relative standard deviations (RSD) ranged from 2.8 to $6.7 \%$. The repeatability and recovery rates were in-line with criteria set by the GB 2763-2019 Guideline. Therefore, this validated method is suitable for the simultaneous determination of multi-class pesticide residues in Wuyi Rock tea.
\end{abstract}

Keywords: GC-MS/MS, QuEChERs, Camellia sinensis, multi-pesticide residues, matrix interference

\section{Introduction}

Tea, the agricultural product made from dried leaves of various cultivars of Camellia sinensis (L.) O. Kuntze, is the most popular non-alcoholic beverage throughout the world, particularly in Asian countries (Nie and Xie, 2011; Sharangi, 2009). Due to its beneficial effects on humans, tea is regarded as a healthy drink and should be free from contaminants. Throughout the growth of the plant, as well as in post-harvest treatments, pesticides are commonly used to protect the tea from weeds, pests, and diseases to guarantee high-quality products (Gurusubramanian et al., 2008). Even though some pesticide residues can be naturally degraded due to their instability, eliminating them completely is a difficult task. Considering that pesticide residues may present health risks to the consumer and potentially adverse influences on the environment, there are 
strict regulations on maximum residues limits (MRLs). These exist for several hundred types of residues in many counties, including Australia, Japan, USA, and China, as well as several international organizations, including the European Union (EU) and the World Health Organization (WHO)/Food and Agriculture Organization (FAO). Based on the EU regulation, which includes a list of more than 480 pesticides, the default MRL of a pesticide residue is generally $0.01 \mathrm{mg} / \mathrm{kg}$ (European Union, 2016), which approaches the detection limit of most analytical methods. Therefore, in order to produce safer tea products, it is necessary to establish and modify a reliable, valid, sensitive, and high-throughput analytical method to simultaneously determine pesticide residues.

The analysis of trace substances in tea samples is challenging due to the significant amount of interference from highly complex compounds such as sugar, alkaloids, polyphenols, fatty acids, organic acids, caffeine, pigments, as well as other pesticides (Guillarme et al., 2010; Xu et al., 2011). Many approaches have been developed to detect the extremely small amounts of multi-class pesticide in tea samples; for example, solid-phase extraction (SPE) (Liu et al., 2019), dispersive solid-phase extraction (dSPE) (Dil et al., 2018), supercritical fluid extraction (SFE) (Huang et al., 2019b), matrix solid phase dispersion (MSPD) (Ramos, 2019), gel permeation chromatography (GPC) (Zhu et al., 2019), dispersive liquid-liquid microextraction (Dil et al., 2019), and magnetic dispersive micro-solid phase extraction (Mehrabi et al., 2017).

Among these methods, an extraction procedure based on the dSPE clean-up step named as QuEChERS (quick, easy, cheap, effective, rugged and safe) is a powerful method of sample preparation, first proposed by Anastassiades et al. (2003) and which has become very popular in the past few years. The technique has been successfully applied to detect one and more groups of pesticide residues in several agricultural products, including fruits and vegetables (Gómez-Ramos et al., 2013), animal-derived food (Surma et al., 2013), milk (Li et al., 2013), and cereals (Zheng et al., 2013). The technique utilizes a single-step or buffered acetonitrile extraction and a salting-out phase which separates the analyte from the water using anhydrous magnesium sulphate. Afterwards, a clean-up step is conducted to eliminate redundant water and interferences with a combination of sorbents containing $\mathrm{MgSO}_{4}$ and sorbent primary secondary amine (PSA). Then, the final extracts undergo separation using either liquid chromatography (LC) or gas chromatography (GC) followed by detection through mass spectrometry (MS) (A.O.A.C., 2010). This method has many merits. First, the final extracts, which are dissolved in acetonitrile, can be utilized both for LC and GC. Secondly, various types of pesticides can be measured by this method in a single procedure. Thirdly, the QuEChERS method is definitely low-cost, simple, fast, solid, safe and effective, as per its name (Lehotay et al., 2005). Currently, the QuEChERS method has been successfully used to extract and purify pesticides from green, black, white, oolong and red tea (Shoeibi et al., 2013; Rajski et al., 2013; Guan et al., 2013; Chen et al., 2014a, b; Tran et al., 2015; Hou et al., 2016; Li et al., 2017; Wu, 2017; Huang et al., 2019a; Yu et al., 2020; Ly et al., 2020). However, several previous QuEChERS methodologies have concentrated on only a few types of pesticide; for example, only seven benzoylurea pesticides were determined in manufactured oolong tea (Chen et al., 2014b). Guan et al. (2013) presented a multi-residue method based on the utilization of a modified QuEChERS protocol combined with LC-MS/MS applied in tea, but only five organophosphorus and six carbamate pesticides were selected. Similarly, Yu et al. (2020) ameliorated the QuEChERS method that used only one absorbent and used LC- 
MS/MS to simultaneously determine ten organophosphorus pesticide residues in tea. Since various classes of pesticides could reside in the tea, it is necessary to explore a novel method to analyze as many types as possible.

In a previous study by $\mathrm{Li}$ et al. (2017), the authors found that GC coupled with tandem mass spectrometry (GC-MS/MS) significantly enhanced the simultaneous determination of multi-pesticide residues due to its high selectivity and sensitivity compared to single quadrupole MS, with low limits of detection (LOD), low limits of quantification (LOQ) and excellent accuracy. The analytical method based on the QuEChERS method followed by GC-MS/MS has been standardized for the determination of 208 pesticides and their metabolite residues in foods of plant origin in China (GB 23200.113-2018), which was implemented on December 1, 2019. However, literature regarding the determination of multi-pesticide residues specifically in tea using GC-MS/MS and QuEChERS (or improved versions) are rare (Wu, 2017).

Teas from different regions have different tastes, flavors, colors, and appearances due to different cultivars, cultivation conditions, climate, and processing technology (Yener et al., 2016). One particular region of interest is Wuyi Mountain, located at the north part of Fujian Province, which is a UNESCO World Heritage site and considered the origin of oolong tea. In recent years, the yield and consumption of oolong tea has raised substantially worldwide thanks to its favorable taste and pleasant aroma (Chen et al., 2011). Moreover, Wuyi Rock tea is considered to be the most prestigious and premium subcategory of oolong tea in China, owing to its special and complicated processing procedures (Chen et al., 2018). The distinct processing steps of Wuyi Rock tea makes the interfering components of tea more abundant and complex, which result in stronger matrix interferences than other tea types. However, to the best of our knowledge, there is little information on pesticide residue analysis in Wuyi Rock tea based on QuEChERS sample pre-treatment combined with GC-MS/MS.

The present study focused on the removal of matrix effects by QuEChERS extraction using acetonitrile mixed with analyte protectants. This was combined with mixed-mode SPE clean-up using different adsorbents (C18, GCB and PSA), and salting-out using anhydrous $\mathrm{NaCl}$ and $\mathrm{MgSO}_{4}$, as part of the sample preparation procedure. As such, a methodology was developed to simultaneously quantify multi-class pesticides in Wuyi Rock tea with low matrix interferences and high recovery rates by GC-MS/MS.

\section{Materials and methods}

\section{Chemicals and reagents}

A total of 33 pesticide reference standards with initial concentrations of $100 \mu \mathrm{g} / \mathrm{mL}$ and purities of $98.0-99.9 \%$ were supplied by the Agro-Environmental Protection Institute, Ministry of Agriculture and Rural Affairs, China (see Table Al in the Appendix). These pesticides were selected based upon their common application on tea plants and could be analyzed through GC-MS/MS. Primary secondary amine (PSA), graphitized carbon black (GCB), and $\mathrm{C} 18$ sorbents were purchased from Agela Technologies (Tianjin, China). HPLC grade acetonitrile and toluene were purchased from Sigma-Aldrich (Merck, Germany). Analytical grade sodium chloride $(\mathrm{NaCl})$ and anhydrous magnesium sulfate $\left(\mathrm{MgSO}_{4}\right)$ were purchased from China National Medicines Corporation Ltd. (Shanghai, China). Heptachlor epoxide with a purity $\geq 98.0 \%$ was used as an internal standard (IS) for GC-MS/MS analysis. The stock IS solution was prepared in acetonitrile to a concentration of $4 \mu \mathrm{g} / \mathrm{mL}$ and preserved at $-20{ }^{\circ} \mathrm{C}$ until 
used. An analyte protectant (AP) solution was also prepared in acetonitrile, comprising $10 \mathrm{mg} / \mathrm{mL}$ of sorbitol and $20 \mathrm{mg} / \mathrm{mL}$ of L-gulonic acid- $\gamma$-lactone (both $\geq 98.0 \%$ purity; Macklin, Shanghai, China).

\section{Instrumentation}

Target analytes were determined using an Agilent 6890 Gas Chromatograph in combination with an Agilent 7000A triple quadrupole mass spectrometer in electron ionization mode $(\mathrm{EI}, 70 \mathrm{eV})$. A DB-5MS capillary column $(30 \mathrm{~m} \times 0.25 \mathrm{~mm}$ i.d. and $0.25-\mu \mathrm{m}$ thick film) was used to separate the analytes. The oven temperature changes in the column were as follows: $40^{\circ} \mathrm{C}$ for $1.5 \mathrm{~min}$; increased by $25^{\circ} \mathrm{C} / \mathrm{min}$ to $90{ }^{\circ} \mathrm{C}$, held for $1.5 \mathrm{~min}$; increased by $25^{\circ} \mathrm{C} / \mathrm{min}$ to $180{ }^{\circ} \mathrm{C}$, then by $5^{\circ} \mathrm{C} / \mathrm{min}$ to $280{ }^{\circ} \mathrm{C}$, then by 10 ${ }^{\circ} \mathrm{C} / \mathrm{min}$ to $300{ }^{\circ} \mathrm{C}$, where it was held for $5 \mathrm{~min}$. The injection volume was $1 \mu \mathrm{L}$ in splitless mode at a constant flow rate of $1 \mathrm{~mL} / \mathrm{min}$; the injector temperature was held at $280{ }^{\circ} \mathrm{C}$. The multiple reaction monitoring mode (MRM) with two transitions for each pesticide was applied to scan the ions, the higher intensities of the precursor-to-product ion transition were utilized for quantification, and the others were applied for confirmation. Retention time (RT), quantitative peak, confirmation peak and collision energy (CE) were set (see Table Al).

For the preparation of tea samples, a disintegrator (FW100, Tianjin Taisite Instrument Co., Ltd, Tianjin, China), nitrogen evaporator (QSC-12T, Quandao, Shanghai, China), high speed centrifuge (TG-16W, Biobase Scientifc Instrument Co., Ltd., Shandong, China) and horizontal oscillator (HT-100W, Zhongkai Scientifc Instrument Co., Ltd., Guangdong, China) were used.

\section{Sample preparation procedure}

The samples used in this study were dried Wuyi Rock tea, which is produced from $C$. sinensis leaves and buds, collected from the local market. Blank samples were selected from the samples in which no pesticides were detected. Five hundred grams of the collected samples were first ground, homogenized, and sieved through a 20-mesh sieve. Two grams of the tea powder was placed into a 50-mL centrifuge tube, to which $1 \mathrm{~g}$ of anhydrous $\mathrm{NaCl}$ and $4 \mathrm{~g}$ of anhydrous $\mathrm{MgSO}_{4}$ were then added. The tube was sealed and hand-shaken for $1 \mathrm{~min}$. Then, $15 \mathrm{~mL}$ of acetonitrile was added, the tube was again shaken vigorously for $1 \mathrm{~min}$, then centrifuged at $4200 \mathrm{r} / \mathrm{min}$ for $10 \mathrm{~min}$. For the cleanup step, $5 \mathrm{~mL}$ of the supernatant was transferred to a $15 \mathrm{~mL}$ centrifuge tube including $400 \mathrm{mg}$ of PSA, $200 \mathrm{mg}$ of GCB, and $100 \mathrm{mg}$ of $\mathrm{C} 18$. The tube was shaken vigorously for $1 \mathrm{~min}$ and centrifuged at $4200 \mathrm{r} / \mathrm{min}$ for $3 \mathrm{~min}$. One milliliter of the supernatant was pipetted and filtered through a $0.22-\mu \mathrm{m}$ filter membrane (Minisart RC 15, Sartorius, Germany) to a GC-MS/MS autosampler vial. Prior to GC injection, the filtered supernatant was re-dissolved in $20 \mu \mathrm{L}$ of the IS solution, and $20 \mu \mathrm{L}$ of AP solution was added to ensure a good signal and peak shape (Wang et al., 2011).

\section{Preparation of matrix-match standards solutions}

Each stock solution of pesticide was prepared at a concentration of $1000 \mathrm{ng} / \mathrm{mL}$ in acetonitrile and stored at $-20{ }^{\circ} \mathrm{C}$ until use. The composite working standard solutions were freshly prepared at concentrations of $0,20,50,100,200$, and $500 \mathrm{ng} / \mathrm{mL}$ by diluting the stock solutions with acetonitrile. The working standard solutions were applied to prepare a standard curve (concentration range from 0 to $500 \mathrm{ng} / \mathrm{mL}$ ) in a 
blank tea sample for obtaining a matrix-match and spike sample for the validation measurement. The pesticide-free tea sample was extracted with acetonitrile using the same above-mentioned method.

\section{Method validation}

The method was validated to investigate linearity, repeatability, accuracy, precision, and limit of quantification (LOQ). Linearity was tested using matrix-matched calibration by analyzing pesticide-free tea samples spiked at six concentration levels, achieved by gradually diluting the mixed standard solution in acetonitrile. Calibration curves were established by plotting the peak areas of analytes/IS ratio against analyte concentration. Based on their concentrations, $\mathrm{x}$ axis, peak area, y axis, which were calculated by regression analysis of standard inspection lines:

$$
y=a+b x
$$

where $\mathrm{a}$ and $\mathrm{b}$ are constant.

Recovery and repeatability experiments were conducted to investigate the accuracy and precision of the method based on three concentration levels (20, 100, and $400 \mu \mathrm{g} / \mathrm{kg}$ ) of each spiked sample with five replicates at every level. LOQs were evaluated at $10 \times \mathrm{S} / \mathrm{N}$ ratios for the target ion (the less intense transition).

\section{Results and discussion}

\section{Optimization of extraction solvent}

To enhance the extraction efficiency and lessen matrix effects, the extraction solvent should possess a similar polarity to that of the pesticides. Earlier research suggested that acetonitrile is an appropriate extraction solvent since it has a suitable polarity for most components and produces less matrix interference from co-extracts and greater recover rates and compatibility with LC and GC systems (da Costa-Morais et al., 2018; Lehotay et al., 2010). In order to obtain the optimal extraction efficiency for pesticides in a tea sample, a recovery experiment was conducted by comparing the addition of either $1 \%$ acetic acid or $10 \%$ ethyl acetate to acetonitrile, for a $100 \mathrm{mg} / \mathrm{kg}$ spiked standard solution of a composite pesticide. The extraction was performed as per the previously mentioned methodology, and each treatment was replicated five times.

Recovery rates of the 33 pesticides used in our study ranged from 65.7\% (acephate) and $106.7 \%$ (bifenthrin) when only acetonitrile was used as the extraction agent (Fig. 1).

Acetic acid improved the recovery of only 3 pesticides (cyfluthrin, thiosulfan, and isocarbophos) whilst lowering the rates of more than 20, with an overall range from $52.4 \%$ (acephate) to $108.3 \%$ (cyfluthrin). A previous study found that $1 \%$ acetic acid added to acetonitrile improved the recovery of alkali-sensitive pesticides, such as pyrethroids in apples, to a satisfactory level (>80\%) without obvious matrix effects (Liu et al., 2009). Similarly, Lehotay et al. (2010) found that an acid buffer extraction method had a higher efficiency and higher recovery rate in fruits and vegetables, which is inconsistent with our research. This may be attributed to the fact that tea extracts contain a large amount of tea polyphenol, a type of weak acid component. Therefore, 
since the tea extract solution may naturally act as an acid buffer, the addition of an extra acid buffer was confirmed as an unnecessary step.

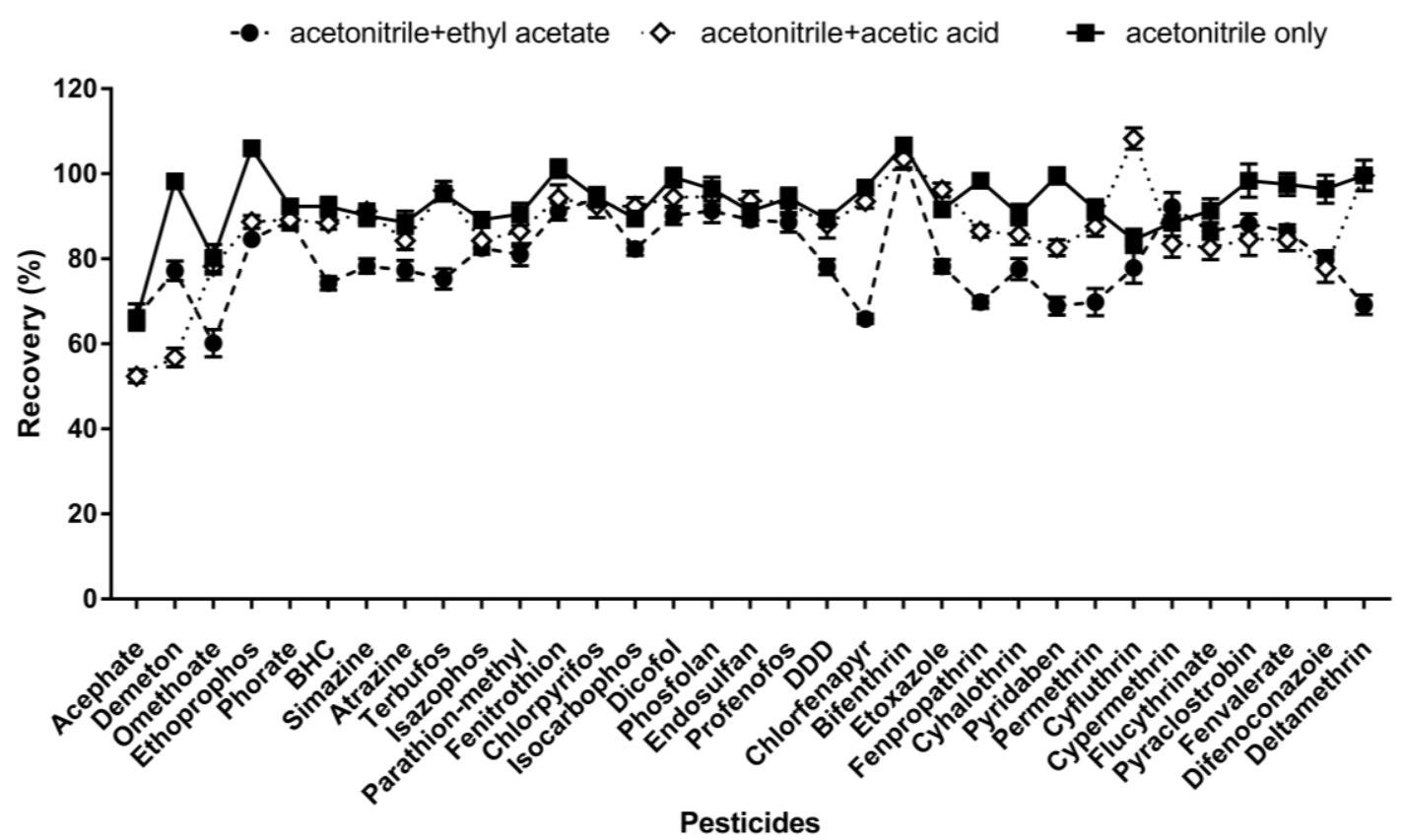

Figure 1. Comparison of three QuEChERS extraction solution combinations for extracting pesticide residues in Wuyi Rock tea (spiked levels $=0.1 \mathrm{mg} / \mathrm{kg}, n=5$ )

When a mixture of acetonitrile and ethyl acetate $(90 \%+10 \%)$ was used as an extraction solvent, the recovery rates ranged from $66.3 \%$ (acephate) to $104.2 \%$ (cyfluthrin), and the mean recovery rate was lower than for acetonitrile only. Additionally, the colors of the extracts from this combination were too intense for further QuEChERS clean-up, in-line with a previous study on tea extracts (Chen et al., 2014b). This may be because ethyl acetate has a weak polarity, which could better dissolve the non-polar or weak polar pesticide components, but also dissolve the nonpolar interference components, making purification more difficult.

Thus, from the above findings, acetonitrile alone was chosen for the preliminary extraction of tea samples.

\section{Addition of analyte protectants (APs)}

The application of APs to compensate for matrix effects in the GC system has recently gained attention ( $\mathrm{Li}$ et al., 2012). In the present study, we compared the peak response of pesticides (spiked at a level of $50 \mu \mathrm{g} / \mathrm{kg}$ ) in acetonitrile solutions containing APs $(10 \mathrm{mg} / \mathrm{mL}$ of sorbitol and $20 \mathrm{mg} / \mathrm{mL}$ L-gulonic acid- $\gamma$-lactone $)$ versus the peak response obtained in acetonitrile alone. All other steps were in accordance with the previously mentioned procedure.

As shown in Figure 2, the response values of targeted pesticides with APs were significantly higher than those of the control. Moreover, the presence of APs significantly improved the peak shape of polar pesticides, such as omethoate and methamidophos, which are easily adsorbed by the liner and injection port. Our results are similar to a previous study which indicated that a mixture of ethylglycerol, 
sorbitol, and L-gulonic acid- $\gamma$-lactone was the most promising combination in reducing the matrix-induced response (Mastovská et al., 2005). Hence, the mixture of $20 \mathrm{mg} / \mathrm{ml} \mathrm{L}$-gulonic acid- $\gamma$-lactone and $10 \mathrm{mg} / \mathrm{ml}$ sorbitol was considered a suitable AP.

(a)

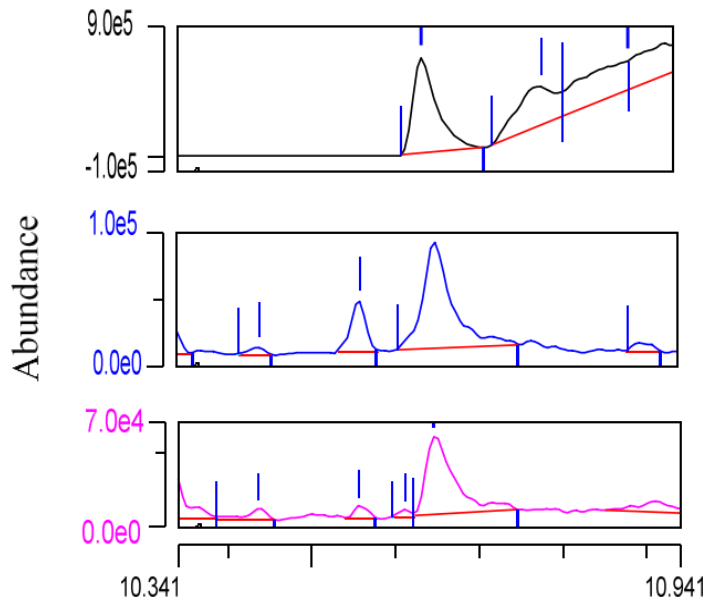

Time (min) (b)
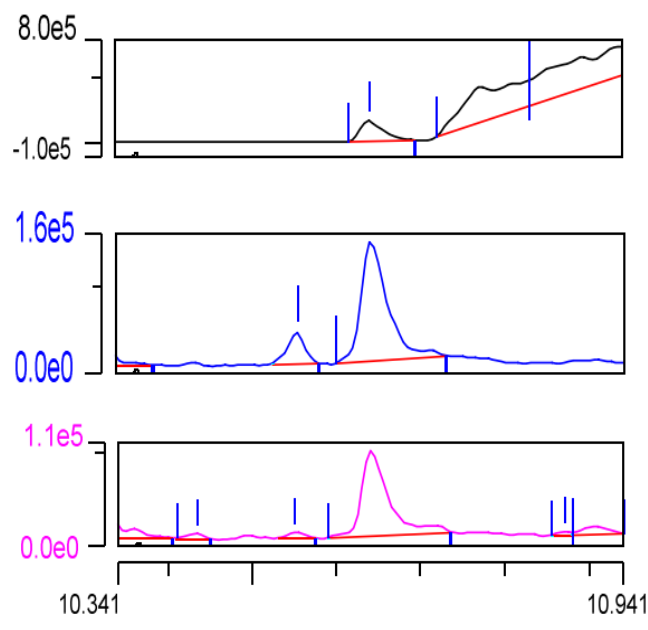

Time (min)

Figure 2. GC-MS/MS chromatograms of omethoate pesticides with (a) and without (b) adding APs (spiked levels $=50 \mathrm{ug} / \mathrm{mL}$ )

\section{Optimization of clean-up conditions}

Tea has a complicated matrix and includes a large amount of interferences, such as tea polyphenols, pigments, fatty acids, and caffeine, which can be co-extracted during sample preparation and influence the chromatographic separation (Pan et al., 2003). In order to solve this problem, we added sorbents (namely PSA, GCB, C18, and anhydrous $\mathrm{MgSO}_{4}$ ) prior to injection as a purification step. PSA is a weak anion exchanger that be responsible for the elimination of sugars, fatty acids and other compounds that can form hydrogen-bonds, while C18 is used to eliminate lipids and non-polar components. GCB is responsible for removing pigments, such as chlorophyll. To remove water residue in the solvent, anhydrous $\mathrm{MgSO}_{4}$ and $\mathrm{NaCl}$ was applied, resulting in a lower polarity of the final acetonitrile extracts and precipitation of certain polar matrix co-extracts (Cajka, et al., 2012). The salting-out conditions and QuEChERS adsorbents were optimized at spiked levels of $100 \mu \mathrm{g} / \mathrm{kg}$ for five replicates. Other than the different salting-out sorbents and QuEChERS adsorbents, all other steps were in performed as per the previously mentioned methodology.

\section{Optimization of salting-out conditions}

Different combinations of anhydrous $\mathrm{NaCl}$ and $\mathrm{MgSO}_{4}$, namely $1 \mathrm{~g} \mathrm{NaCl}+4 \mathrm{~g}$ $\mathrm{MgSO}_{4}, 1 \mathrm{~g} \mathrm{NaCl}+2 \mathrm{~g} \mathrm{MgSO}_{4}$, and $4 \mathrm{~g} \mathrm{MgSO}_{4}$ without $\mathrm{NaCl}$, were compared based on the recovery rate experiments. As shown in Figure 3, the different combinations of anhydrous $\mathrm{NaCl}$ and $\mathrm{MgSO}_{4}$ have significant impacts on the recovery rate of pesticides. For $1 \mathrm{~g} \mathrm{NaCl}+4 \mathrm{~g} \mathrm{MgSO}_{4}$, the recovery value ranged from $77.3 \%$ to $106 \%$, meaning 
that it was more suitable for consistent multi-residue extraction than the other two groups. For $1 \mathrm{~g} \mathrm{NaCl}+2 \mathrm{~g} \mathrm{MgSO}_{4}$ and $4 \mathrm{~g} \mathrm{MgSO}_{4}$ without $\mathrm{NaCl}$, the recovery rates were $53.2-103.5 \%$ and $65.4-107.8 \%$, respectively. When acetonitrile was used as the extractant, the combination of anhydrous $\mathrm{MgSO}_{4}$ and $\mathrm{NaCl}$ improved the recovery of polar pesticides, but too much $\mathrm{NaCl}$ was unfavorable for improving the recovery rate (Anastassiades et al., 2003; Andersson et al., 1991). Based on the current EU guidelines for quality control in pesticide residue determination (SANCO/10232/2006, 2006), the recovery values from routine analysis should be between $60 \%$ and $140 \%$. Thus, $1 \mathrm{~g}$ $\mathrm{NaCl}+4 \mathrm{~g} \mathrm{MgSO}_{4}$ was selected as the optimal combination.

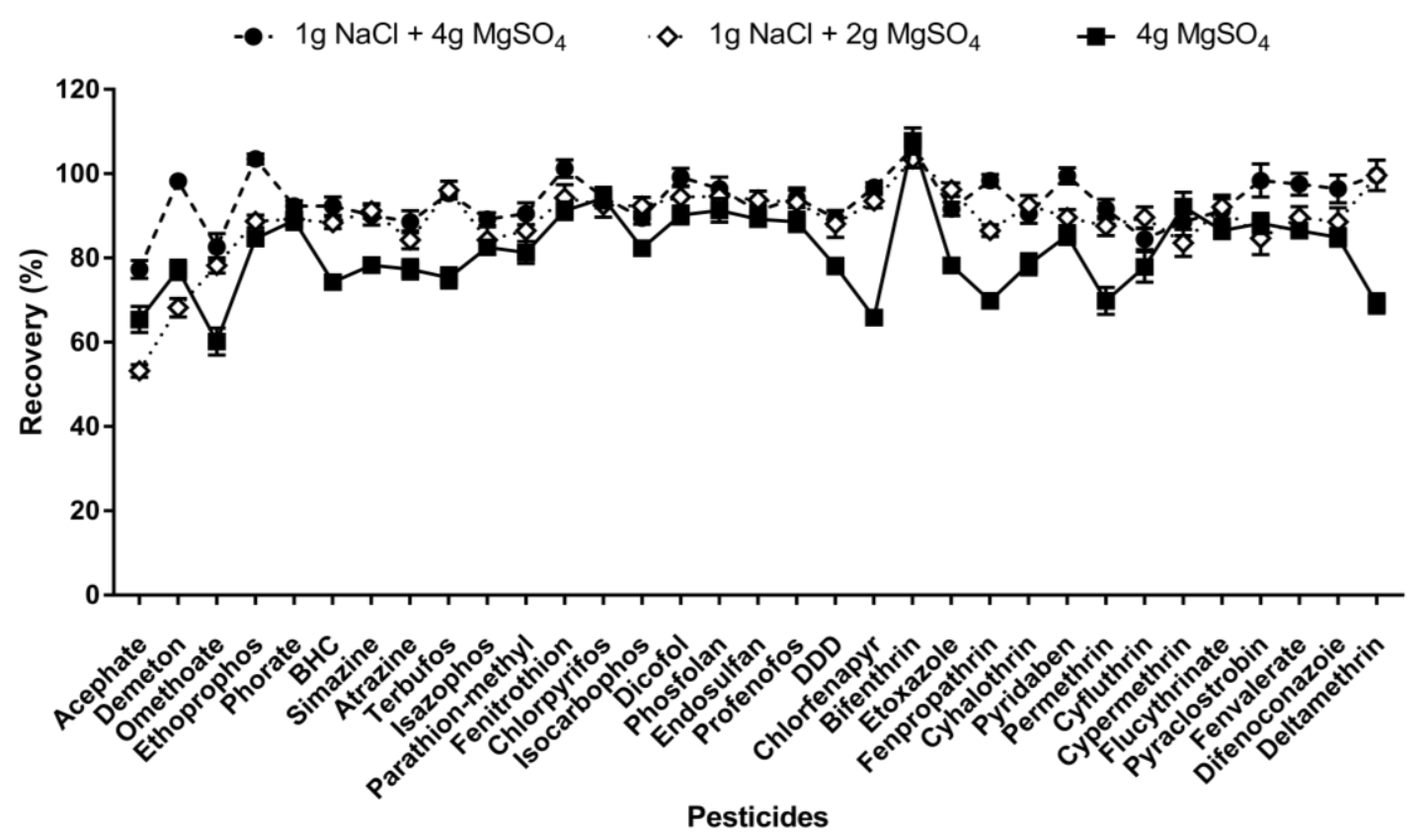

Figure 3. Comparison of three QuEChERS salting-out solutions for purifying extracts in Wuyi Rock tea (spiked levels $=1 \mathrm{mg} / \mathrm{kg}, n=5$ )

\section{Optimization of QuEChERS adsorbents}

The main purpose of QuEChERS clean-up is to absorb as much interfering matrix as possible and maintain the targeted compounds in the solution without any negative effects. PSA has been suggested as a suitable adsorbent for eliminating interfering substances among the several carbon materials during the QuEChERS clean-up procedure for tea samples (Yu et al., 2020). To ensure optimal clean-up efficiency, recovery experiments were conducted by comparing different combinations of $\mathrm{C} 18$ and GCB with $400 \mathrm{mg}$ of PSA. These were $400 \mathrm{mg}$ PSA with $400 \mathrm{mg}$ GCB $+50 \mathrm{mg} \mathrm{C} 18$ (combination adsorbent A), $400 \mathrm{mg}$ PSA with $600 \mathrm{mg} \mathrm{GCB}+50 \mathrm{mg}$ C18 (combination adsorbent B), and $400 \mathrm{mg}$ PSA with $400 \mathrm{mg}$ GCB $+100 \mathrm{mg}$ C18 (combination adsorbent $\mathrm{C}$ ). According to the results shown in Figure 4, the recovery rates using combinations A, B, and $\mathrm{C}$ were $56.3-114.6 \%, 53.1-102.8 \%$, and $78.4-108.6 \%$, respectively. Only the rates resulting from $\mathrm{C}$ were within the range of the $\mathrm{EC}$ guidelines (SANCO/10232/2006, 2006). Moreover, the recovery rates of all 33 pesticides were more stable and greater than $78.4 \%$, when combination adsorbent $\mathrm{C}$ was used. The use of combination adsorbent $\mathrm{B}$ resulted in very low recovery rates for chlorpyrifos, 
fenvalerate, cyhalothrin, and DDT, although other pesticides were greater than $100 \%$. Previous studies have indicated that increasing the volume of GCB led to reduced recovery rates of some pesticides due to the strong retention ability of GCB for these pesticides (Walorczyk and Gnusowski, 2009; Lu et al., 2012; Zheng et al., 2013). GCB possesses a planar structure, and therefore particularly adsorbs pesticides with planar structures, thus leading to low recovery rates for these pesticides (Tran et al., 2015). When combination adsorbent A was used, the test solution was light green, which indicated that the pigment was not cleaned completely. In summary, combination adsorbent C (400 mg PSA + $400 \mathrm{mg}$ GCB + $100 \mathrm{mg} \mathrm{C18}$ ) was found to the most suitable QuEChERS adsorbents for Wuyi Rock tea samples.

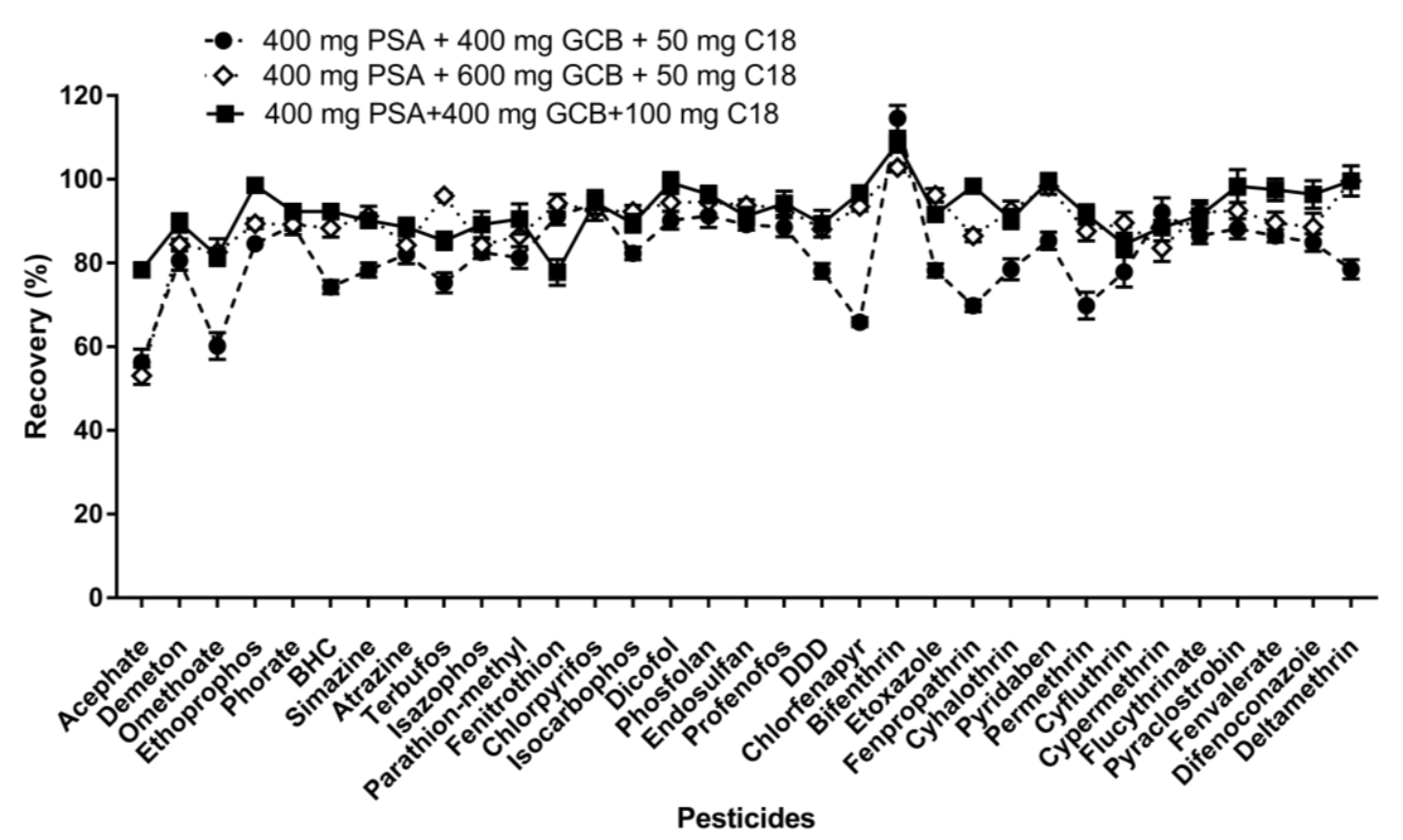

Figure 4. Comparison of three QuEChERS adsorbent combinations for purifying extracts in Wuyi Rock tea (spiked levels $=1 \mathrm{mg} / \mathrm{kg}, n=5$ )

\section{Method validation}

The calibration curve was prepared using matrix-matched standards analyzed at five concentration levels $(20,50,100,200$, and $500 \mathrm{ng} / \mathrm{mL})$. The results, shown in Table 1, indicate that good linearity with correlation coefficients $\left(R^{2}\right)$ greater than 0.994 was obtained for all pesticides at the concentration levels of $0.02,0.2,0.4 \mathrm{mg} / \mathrm{kg}$ after six parallel determinations. For all analyzed pesticides at three levels of concentration, the relative standard deviations (RSD\%) ranged from $2.8 \%$ to $6.7 \%$, with recovery rates between $72.3 \%$ and $110.6 \%$. This suggests that this method has an accuracy appropriate for quantifying multi-class pesticide residues in Wuyi Rock tea. The limit of quantification (LOQ) for this determination method were estimated in spiked samples and calculated by considering a signal-to-noise ratio $(\mathrm{S} / \mathrm{N})$ of 10:1. All pesticides could be quantified at $0.02 \mathrm{mg} / \mathrm{kg}$ without any concentration steps; LOQ values ranged from 1.8 to $15.5 \mu \mathrm{g} / \mathrm{kg}$ and were acceptable compared to the maximum residue level from GB 2763-2019. Therefore, this method is suitable for the trace determination of pesticide multi-residue in Wuyi Rock tea. 
Table 1. Linearity, limits of quantification ( $L O Q)$ and recovery rates obtained with a modified QuEChERS method in Wuyi Rock tea, analyzed by GC-MS/MS $(n=6)$

\begin{tabular}{|c|c|c|c|c|c|c|c|c|}
\hline \multirow{2}{*}{ Pesticide } & \multirow{2}{*}{$R^{2}$} & \multirow{2}{*}{$\begin{array}{c}\text { LOQ } \\
(\mu \mathrm{g} / \mathrm{kg})\end{array}$} & \multicolumn{2}{|c|}{ Spiked level = $0.02 \mathrm{mg} / \mathrm{kg}$} & \multicolumn{2}{|c|}{ Spiked level = $0.2 \mathrm{mg} / \mathrm{kg}$} & \multicolumn{2}{|c|}{ Spiked level = $0.4 \mathrm{mg} / \mathrm{kg}$} \\
\hline & & & Recovery (\%) & RSD (\%) & Recovery (\%) & RSD (\%) & Recovery (\%) & RSD (\%) \\
\hline Acephate & 0.9948 & 15.3 & 72.3 & 4.3 & 78.1 & 3.9 & 81.6 & 2.9 \\
\hline Demeton & 0.9994 & 13.2 & 102.1 & 5.2 & 95.3 & 2.2 & 92.3 & 2.6 \\
\hline Omethoate & 0.9991 & 10.6 & 83.2 & 3.5 & 88.6 & 4.6 & 79.6 & 2.8 \\
\hline Ethoprophos & 0.9999 & 6.8 & 106.3 & 2.6 & 102.3 & 2.1 & 88.6 & 3.1 \\
\hline Phorate & 0.9991 & 8.6 & 94.2 & 3.7 & 95.3 & 1.6 & 94.5 & 2.1 \\
\hline$\alpha-\mathrm{BHC}$ & 0.9997 & 3.4 & 99.6 & 2.8 & 88.4 & 3.2 & 79.1 & 1.6 \\
\hline Simazine & 0.9991 & 6.9 & 94.2 & 1.6 & 96.5 & 2.3 & 96.4 & 2.1 \\
\hline Atrazine & 0.9957 & 12.6 & 96.8 & 3.6 & 94.3 & 2.8 & 89.3 & 1.8 \\
\hline$\beta$-BHC & 0.9997 & 4.8 & 89.5 & 2.8 & 88.6 & 1.6 & 99.3 & 3.1 \\
\hline$\gamma$-BHC & 0.9997 & 6.1 & 90.8 & 3.9 & 93.2 & 2.5 & 87.4 & 2.8 \\
\hline Terbufos & 0.9991 & 5.9 & 84.9 & 5.1 & 90.5 & 3.1 & 95.2 & 1.2 \\
\hline Isazophos & 0.9985 & 8.7 & 94.2 & 3.8 & 95.3 & 2.6 & 91.8 & 0.6 \\
\hline$\delta$-BHC & 0.9998 & 6.3 & 81.4 & 2.4 & 83.4 & 2.0 & 83.9 & 2.1 \\
\hline Parathion-methyl & 0.9976 & 5.2 & 95.2 & 1.6 & 91.2 & 1.6 & 79.6 & 1.0 \\
\hline Fenitrothion & 0.9998 & 8.7 & 102.5 & 3.1 & 94.6 & 2.5 & 95.6 & 1.3 \\
\hline Chlorpyrifos & 0.9989 & 6.3 & 96.5 & 2.8 & 93.1 & 1.3 & 89.2 & 0.9 \\
\hline Isocarbophos & 0.9992 & 4.9 & 94.1 & 4.6 & 97.6 & 0.5 & 94.6 & 2.1 \\
\hline Dicofol & 0.9993 & 1.8 & 96.8 & 2.1 & 89.3 & 2.3 & 88.7 & 1.3 \\
\hline Quinalphos & 0.9989 & 11.3 & 97.2 & 1.8 & 91.8 & 2.4 & 93.1 & 1.8 \\
\hline Phosfolan & 0.9997 & 6.2 & 99.2 & 4.5 & 97.2 & 3.2 & 89.4 & 2.6 \\
\hline Endosulfan & 0.9999 & 4.1 & 99.4 & 3.9 & 88.9 & 2.5 & 95.3 & 3.5 \\
\hline Profenofos & 0.9992 & 13.5 & 95.6 & 3.1 & 95.6 & 1.4 & 87.4 & 1.4 \\
\hline p.p $p^{\prime}-\mathrm{DDE}$ & 0.9995 & 6.4 & 86.5 & 5.8 & 89.2 & 1.1 & 86.3 & 0.5 \\
\hline Chlorfenapyr & 0.9998 & 8.5 & 99.6 & 3.5 & 94.5 & 2.5 & 92.1 & 1.3 \\
\hline p.p $p^{\prime}-$ DDD & 0.9996 & 8.4 & 88.2 & 4.1 & 92.3 & 1.6 & 95.7 & 0.8 \\
\hline o.p'-DDT & 0.9994 & 6.3 & 87.9 & 3.2 & 94.0 & 3.2 & 98.4 & 1.2 \\
\hline p.p $p^{\prime}-$ DDT & 0.9996 & 7.4 & 92.6 & 2.8 & 85.6 & 1.7 & 101.0 & 1.9 \\
\hline Bifenthrin & 0.9948 & 5.2 & 110.6 & 2.6 & 101.2 & 2.8 & 98.6 & 1.3 \\
\hline Etoxazole & 0.9967 & 7.6 & 98.4 & 3.1 & 95.3 & 3.5 & 84.3 & 2.5 \\
\hline Fenpropathrin & 0.9999 & 5.2 & 99.8 & 4.8 & 93.1 & 1.9 & 96.5 & 1.6 \\
\hline Cyhalothrin & 0.9999 & 15.5 & 86.5 & 5.0 & 82.3 & 2.0 & 86.7 & 2.8 \\
\hline Pyridaben & 0.9998 & 8.9 & 97.5 & 3.5 & 94.6 & 3.3 & 95.2 & 1.3 \\
\hline Permethrin & 0.9978 & 14.7 & 89.4 & 4.7 & 88.6 & 2.1 & 84.5 & 3.5 \\
\hline Cyfluthrin & 0.9993 & 12.6 & 102.5 & 2.3 & 97.1 & 2.4 & 93.2 & 3.2 \\
\hline Cypermethrin & 0.9998 & 10.4 & 99.5 & 4.1 & 89.5 & 3.1 & 88.6 & 1.2 \\
\hline Flucythrinate & 0.9999 & 8.4 & 98.3 & 3.5 & 95.4 & 2.5 & 95.8 & 2.0 \\
\hline Pyraclostrobin & 0.9996 & 6.6 & 94.6 & 2.9 & 91.5 & 1.8 & 79.6 & 1.6 \\
\hline Fenvalerate & 0.9999 & 7.8 & 98.4 & 3.3 & 97.4 & 3.6 & 96.4 & 2.1 \\
\hline Difenoconazoie & 0.9999 & 6.5 & 102.3 & 4.6 & 92.8 & 2.9 & 89.1 & 3.6 \\
\hline Deltamethrin & 0.9996 & 11.6 & 98.9 & 3.8 & 97.1 & 1.4 & 92.4 & 2.1 \\
\hline
\end{tabular}

\section{Conclusion}

QuEChERS is a tried and tested approach for determining pesticide residues in fruit and vegetables. However, in Wuyi Rock tea there are many complex chemical substances that cause matrix interferences and seriously influence the detection limits for pesticide analysis. Moreover, whilst most QuEChERS extraction methods are sufficient for LC/MS/MS analysis (Chen et al., 2014b; Guan et al., 2013; Rajski et al., 2013; Tran et al., 2015; Li et al., 2017; Huang et al., 2019a; Yu et al., 2020; Ly et al., 2020), few papers have focused on GC/MS/MS analysis to reduce matrix interference. 
Thus, in the present study, a modified QuEChERS preparation method was developed to simultaneously quantify 33 pesticide residues in Wuyi Rock tea using GCMS/MS. This involved applying a QuEChERS extraction and clean-up technique with three different adsorbents (PSA, GCB, and C18), salting-out sorbents (anhydrous $\mathrm{MgSO}_{4}$ and $\mathrm{NaCl}$ ), and analyte protectants (L-gulonic acid- $\gamma$-lactone and sorbitol) to minimize matrix interference, before analysis through a gas chromatography system coupled to tandem mass spectrometry. The results exhibited good analytical performance based on the repeatability and recovery obtained in the Wuyi Rock tea matrices, demonstrating that this quantitative method is suitable for the accurate analysis of pesticide multi-residue in tea samples.

Compared with the traditional method of pesticide analysis, the modified QuEChERS method has proven to be fast, easy to conduct, and uses only small quantities of reagents. It is therefore more environmentally friendly than conventional methods. To the best of our knowledge, this is the first time that the pesticide levels of Wuyi Rock tea in Fujian Province, China has been recorded; our data offers valuable information for the supervision department in China. In future research, the QuEChERS sample prepare method could also be optimized and validated for analysis through LC$\mathrm{MC} / \mathrm{MC}$ for polar, thermally unstable, and non-volatile pesticide residues in tea. Furthermore, we plan to use a similar methodology to optimize and evaluate pesticides in other tea commodities (e.g. black, white, and green tea) collected from different locations in China. Finally, the risk posed by pesticides in various tea infusions also warrants investigation.

Acknowledgements. This work was sponsored by the Education and Scientific Research Project for Young and Middle-aged Teachers in Fujian Province (JAT190793), the Advanced Talents Introduction Project of Wuyi University (YJ201910), and Science \& Technology Innovation Platform Construction Project of Fujian Province (2018N2004).

Conflict of interests. The authors declare that they have no known competing financial interests or personal relationships that could have appeared to influence the work reported in this paper.

\section{REFERENCES}

[1] Anastassiades, M., Lehotay, S. J., Stajnbaher, D. Schenck, F. J. (2003): Fast and easy multiresidue method employing acetonitrile extraction/partitioning and dispersive solidphase extraction for the determination of pesticide residues in produce. - Journal of AOAC International 86: 412-431.

[2] Andersson, A., Pålsheden, H. (1991): Comparison of the efficiency of different GLC multi-residue methods on crops containing pesticide residues. - Fresenius' Journal of Analytical Chemistry 339(6): 365-367.

[3] A.O.A.C. (2010): Official Methods of Analysis (18th rev. 3) - In: Horwitz, W., Latimer, G. W. (eds.) Official Method 2007.01 Pesticide Residues in Foods by Acetonitrile Extraction and Partitioning with Magnesium Sulfate. Association of Official Analytical Chemists, Inc., Guithersburg, MD, pp. 17-26.

[4] Cajka, T., Sandy, C., Bachanova, V., Drabova, L., Kalachova, K., Pulkrabova, J., Hajslova, J. (2012): Streamlining sample preparation and gas chromatography-tandem mass spectrometry analysis of multiple pesticide residues in tea. - Analytica Chimica Acta 743: 51-60. 
[5] Chen., Y. L., Duan, J., Jiang, Y. M., Shi, J., Peng, L., Xue, S., Kakuda, Y. (2011): Production, quality, and biological effects of oolong tea (Camellia sinensis). - Food Research International 27: 1-15.

[6] Chen, H., Yin, P., Wang, Q., Jiang, Y., Xin, L. (2014a): A modified QuEChERS sample preparation method for the analysis of 70 pesticide residues in tea using gas chromatography-tandem mass spectrometry. - Food Analytical Methods 7(8): 15771587.

[7] Chen, L., Chen, J., Guo, Y., Li, J., Yang, Y., Xu, L., Fu, F. (2014b): Study on the simultaneous determination of seven benzoylurea pesticides in oolong tea and their leaching characteristics during infusing process by HPLC-MS/MS. - Food Chemistry 143: 405-410.

[8] Chen, S., Li, M., Zheng, G., Wang. T., Lin, J., Wang, S., Wang, X., Chao, Q., Cao, S., Yang, Z., Yu, X. (2018): Metabolite profiling of 14 Wuyi Rock Tea cultivars using UPLC-QTOF MS and UPLC-QqQ MS combined with chemometrics. - Molecules 81(2): 321 .

[9] da Costa-Morais, E. H., Collins, C. H., Jardim, I. C. S. F. (2018): Pesticide determination in sweet peppers using QuEChERS and LC-MS/MS. - Food Chemistry (249): 77-83.

[10] Dil, E. A., Ghaedi, M., Asfaram, A., Mehrabi, F., Bazrafshan, A. A. (2018): Optimization of process parameters for determination of trace hazardous dyes from industrial wastewaters based on nanostructures materials under ultrasound energy. Ultrasonics Sonochemistry 40: 238-248.

[11] Dil, E. A., Ghaedi, M., Asfaram, A., Tayebi, L., Mehrabi, F. (2019): A ferrofluidic hydrophobic deep eutectic solvent for the extraction of doxycycline from urine, blood plasma and milk samples prior to its determination by high-performance liquid chromatography-ultraviolet. - Journal of Chromatography A 1613: 460695.

[12] European Union. (2016): Pesticide residues and maximum residue levels. http://ec.europa.eu/food/plant/pesticides/eu-pesticides-

database/public/?event=download. MRL (accessed: July 2019).

[13] GB 23200.113-2018 National Standard for Food Safety: Determination of 208 pesticide residues and their metabolites in plant-derived foods by gas chromatography-mass spectrometry.

[14] GB 2763-2019 National Food Safety Standard Maximum Limit of Pesticide Residues in Food.

[15] Gómez-Ramos, M. M., Ferrer, C., Malato, O., Agüera, A., Fernández-Alba, A. R. (2013): Liquid chromatography-high-resolution mass spectrometry for pesticide residue analysis in fruit and vegetables: screening and quantitative studies. - Journal of Chromatography A 1287: 24-37.

[16] Guan, Y., Tang, H., Chen, D., Xu, T., Li, L. (2013): Modified QuEChERS method for the analysis of 11 pesticide residues in tea by liquid chromatography-tandem mass spectrometry. - Analytical Methods 5(12): 3056-3067.

[17] Guillarme, D., Casetta, C., Bicchi, C., Veuthey, J. L. (2010): High throughput qualitative analysis of polyphenols in tea samples by ultra-high pressure liquid chromatography coupled to UV and mass spectrometry detectors. - Journal of Chromatography A 1217: 6882-6890.

[18] Gurusubramanian, G., Rahman, A., Sarmah, M., Roy, S., Bora, S. (2008): Pesticide usage pattern in tea ecosystem, their retrospects and alternative measures. - Journal of Environmental Biology 29(6): 813-826.

[19] Hou, X., Lei, S., Guo, L., Qiu, S. (2016): Optimization of a multi-residue method for 101 pesticides in green tea leaves using gas chromatography-tandem mass spectrometry. - Brazilian Journal of Pharmacognosy 26(4): 401-407. 
[20] Huang, Y. S., Shi, T., Luo, X., Xiong, H. L., Min, F. F. (2019a): Determination of multi-pesticide residues in green tea with a modified QuEChERS protocol coupled to HPLC-MS/MS. - Food Chemistry 275: 255-264.

[21] Huang, Y., Wang, T., Fillet, M., Crommen, J., Jiang, Z. (2019b): Simultaneous determination of amino acids in different teas using supercritical fluid chromatography coupled with single quadrupole mass spectrometry. - Journal of Pharmaceutical Analysis 9(4): 254-258.

[22] Lehotay, S. J., Kok, A., Hiemstra, M., Bodegraven, P. (2005): Validation of a fast and easy method for the determination of residues from 229 pesticides in fruits and vegetables using gas and liquid chromatography and mass spectrometric detection. Journal of AOAC International 88: 595-614.

[23] Lehotay, S. J., Son, K. A., Kwon, H., Koesukwiwat, U., Fu, W., Mastovska, K., Hoh, E., Leepipatpiboon, N. (2010): Comparison of QuEChERS sample preparation methods for the analysis of pesticide residues in fruits and vegetables. - Journal of Chromatography 1217(16): 2548-2560.

[24] Li, Y., Chen, X., Fan, C., Pang, G. F. (2012): Compensation for matrix effects in the gas chromatography-mass spectrometry analysis of 186 pesticides in tea matrices using analyte protectants. - Journal of Chromatography 1266: 131-142.

[25] Li, N., Lei, L., Nian, L., Zhang, R., Wu, S. T., Ren, R. B., Wang, Y. Q., Zhang, H. Q., Yu, A. M. (2013): A modified QuEChERS method for the determination of some herbicides in yogurt and milk by high performance liquid chromatography. - Talanta 105: 219-228.

[26] Li, J. X., Sun, M. Y., Chang, Q. Y., Hu, X. Y., Kang, J., Fan, C. L. (2017): Determination of pesticide residues in teas via QuEChERS combined with dispersive liquid-liquid microextraction followed by gas chromatography-tandem mass spectrometry. - Chromatographia 80: 1447-1458.

[27] Liu, Y. B., Fan, M. T., Liang, J., Zhao, Z. Y., Yuan, H. (2009): Determination of 4 pyrethroids in apple by QuEChERS-GC-ECD. - Acta Agriculturae BorealiOccidentalis Sinica 18(4): 61-65.

[28] Liu, C., Ji, Y., Jiang, X., Yuan, X., Zhang, X., Zhao, L. (2019): The determination of pesticides in tea samples followed by magnetic multiwalled carbon nanotube-based magnetic solid-phase extraction and ultra-high performance liquid chromatography tandem mass spectrometry. - New Journal of Chemistry 43(14): 5395-5403.

[29] Lu, D. S., Qiu, X. L., Feng, C., Jin, Y. E., Lin, Y. J., Xiong, L. B., Wen, Y. M., Wang, D. L., Wang, G. Q. (2012): Simultaneous determination of 45 pesticides in fruit and vegetable using an improved QuEChERS method and online gel permeation chromatography-gas chromatography/mass spectrometer. - Journal of Chromatography B 895-896: 17-24.

[30] Ly, T. K., Ho, T. D., Behra, P., Nhu-Trang, T. D. (2020): Determination of 400 pesticide residues in green tea leaves by UPLC-MS/MS and GC-MS/MS combined with QuEChERS extraction and mixed-mode SPE clean-up method. - Food Chemistry 326: 126928.

[31] Mastovská, K., Lehotay, S. J., Anastassiades, M. (2005): Combination of analyte protectants to overcome matrix effects in routine $\mathrm{GC}$ analysis of pesticide residues in food matrixes. - Analytical Chemistry 77: 8129.

[32] Mehrabi, F., Vafaei, A., Ghaedi, M., Ghaedi, M. A., Dil, E. A., Asfaram, A. (2017): Ultrasound assisted extraction of Maxilon Red GRL dye from water samples using cobalt ferrite nanoparticles loaded on activated carbon as sorbent: optimization and modeling. - Ultrasonics Sonochemistry 38: 672-680.

[33] Nie, S. P., Xie, M. Y. (2011): A review on the isolation and structure of tea polysaccharides and their bioactivities. - Food Hydrocolloid 25(2): 144-149. 
[34] Pan, X., Niu, G., Liu, H. (2003): Microwave-assisted extraction of tea polyphenols and tea caffeine from green tea leaves. - Chemical Engineering and Processing: Process Intensification 42(2): 129-133.

[35] Rajski, L., Lozano, A., Belmonte-valles, N., Ucles, A., Ucles, S., Mezcua, M., Fernandez-alba, A. R. (2013): Comparison of three multiresidue methods to analyse pesticides in green tea with liquid and gas chromatography/tandem mass spectrometry. - Analyst 138: 921-931.

[36] Ramos, L. (2019): Use of new tailored and engineered materials for matrix solid-phase dispersion. - Trends in Analytical Chemistry 118: 751-758.

[37] SANCO/10232/2006. (2006): Quality control procedures for pesticide residue analysis. - http://www.crlpesticides.eu/library/docs/allcrl/AqcGuidance_Sanco_2006_10232.pdf (accessed 10.02.20).

[38] Sharangi, A. B. (2009): Medicinal and therapeutic potentialities of tea (Camellia sinensis L.) - a review. - Food Research International 42: 529-535.

[39] Shoeibi, S., Amirahmadi, M., Rastegar, H., Khosokhavar, R., Khanghah, A. M. (2013): An applicable strategy for improvement recovery in simultaneous analysis of 20 pesticides residue in tea. - Journal of Food Science 78: 792-796.

[40] Surma, M. K., Sadowska-Rociek, A. B., Cielik, E. J. (2014): Evaluation of the QuEChERS method with GC-MS detection for the determination of organochlorine pesticides in food of animal origin. - Food Analytical Methods 7(2): 366-376.

[41] Tran, S. C., Le, H. T., Thai-Nguyen, T. H. (2015): Determination of pesticide multiresidues in green tea using a modified QuEChERS extraction and liquid chromatography tandem mass spectrometry technique. - Acta Alimentaria 44(3): 412422.

[42] Walorczyk, S., Gnusowski, B. (2009): Development and validation of a multi-residue method for the determination of pesticides in honeybees using acetonitrile-based extraction and gas chromatography - tandem quadrupole mass spectrometry. - Journal of Chromatography A 1216(37): 6522-6531.

[43] Wang, Y., Jin, H. Y., Ma, S. C., Lu, J., Lin, R. C. (2011): Determination of 195 pesticide residues in Chinese herbs by gas chromatography-mass spectrometry using analyte protectants. - Journal of Chromatography 1218(2): 334-342.

[44] Wu, C. C. (2017): Multiresidue method for the determination of pesticides in Oolong tea using QuEChERS by gas chromatography - triple quadrupole tandem mass spectrometry. - Food Chemistry 229: 580-587.

[45] Xu, X. M., Yu, C., Han, J. L., Li, J. P., El-Sepai, F., Zhu, Y., Huang, B. F., Cai, Z. X., Wu, H. W., Ren, Y. P. (2011): Multi-residue analysis of pesticides in tea by online SEC-GC/MS. - Journal of Separation Science 34(2): 210-216.

[46] Yener, S., Sánchez-López, J. A., Granitto, P. M., Cappellin, L., Märk, T. D., Zimmermann, R., Bonn, G. K., Yeretzian, C., Biasioli, F. (2016): Rapid and direct volatile compound profiling of black and green teas (Camellia sinensis) from different countries with PTR-ToF-MS. - Talanta 152: 45-53.

[47] Yu, C. C., Hao, D. Y., Chu, Q., Wang, T., Liu, S. N., Lan, T., Wang, F. H., Pan, C. P. (2020): A one adsorbent QuEChERS method coupled with LC-MS/MS for simultaneous determination of 10 organophosphorus pesticide residues in tea. - Food Chemistry 321: 126657.

[48] Zheng, H. B., Zhao, Q., Mo, J. Z., Huang, Y. Q., Luo, Y. B., Yu, Q. W., Feng, Y. Q. (2013): Quick, easy, cheap, effective, rugged and safe method with magnetic graphitized carbon black and primary secondary amine as adsorbent and its application in pesticide residue analysis. - Journal of Chromatography A 1300: 127-133.

[49] Zhu, B., Xu, X., Luo, J., Jin, S., Chen, W., Liu, Z., Tian, C. (2019): Simultaneous determination of 131 pesticides in tea by on-line GPC-GC-MS/MS using graphitized multi-walled carbon nanotubes as dispersive solid phase extraction sorbent. - Food Chemistry 276: 202-208. 


\section{APPENDIX}

Table A1. List of targeted pesticides with GC retention times and MS/MS condition

\begin{tabular}{|c|c|c|c|c|c|}
\hline Pesticide & $\begin{array}{l}\text { Chemical } \\
\text { formula }\end{array}$ & CAS No. & Class & $\begin{array}{c}\text { Retention } \\
\text { time/min }\end{array}$ & $\begin{array}{l}\text { MRM transition } / \mathbf{m} / \mathbf{z} \\
\text { (collision energy } / \mathrm{eV} \text { ) }\end{array}$ \\
\hline $\begin{array}{l}\text { Heptachlor } \\
\text { epoxide }\end{array}$ & $\mathrm{C}_{10} \mathrm{H}_{5} \mathrm{Cl}_{7} \mathrm{O}$ & $1024-57-3$ & $\begin{array}{l}\text { Organochlorine } \\
\text { insecticides }\end{array}$ & 16.094 & $\begin{array}{l}354.8-264.9(10)^{\mathrm{a}} \\
352.8-262.9(10)^{\mathrm{b}} \\
\end{array}$ \\
\hline Acephate & $\mathrm{C}_{4} \mathrm{H}_{10} \mathrm{NO}_{3} \mathrm{PS}$ & $30560-19-1$ & $\begin{array}{l}\text { Organophosphorus } \\
\text { insecticides }\end{array}$ & 9.560 & $\begin{array}{l}136.0-94.0(10)^{\mathrm{a}} \\
136.0-42.0(5)^{\mathrm{b}}\end{array}$ \\
\hline Demeton & $\mathrm{C}_{8} \mathrm{H}_{19} \mathrm{O}_{3} \mathrm{PS}_{2}$ & $8065-48-3$ & $\begin{array}{l}\text { Organophosphorus } \\
\text { insecticides }\end{array}$ & 10.670 & $\begin{array}{l}171.1-115(10)^{\mathrm{a}} \\
88.1-59.8(6)^{\mathrm{b}}\end{array}$ \\
\hline Omethoate & $\mathrm{C}_{5} \mathrm{H}_{12} \mathrm{NO}_{4} \mathrm{PS}$ & 1113-02-6 & $\begin{array}{l}\text { Organophosphorus } \\
\text { insecticides }\end{array}$ & 10.814 & $\begin{array}{l}110.0-79.0(10)^{\mathrm{a}} \\
156.0-110.0(8)^{\mathrm{b}}\end{array}$ \\
\hline Ethoprophos & $\mathrm{C}_{8} \mathrm{H}_{19} \mathrm{O}_{2} \mathrm{PS}_{2}$ & $13194-48-4$ & $\begin{array}{l}\text { Organophosphorus } \\
\text { insecticides }\end{array}$ & 10.952 & $\begin{array}{l}157.9-96.9(16)^{\mathrm{a}} \\
157.9-113.9(6)^{\mathrm{b}}\end{array}$ \\
\hline Phorate & $\mathrm{C}_{7} \mathrm{H}_{17} \mathrm{O}_{2} \mathrm{PS}_{3}$ & $298-02-2$ & $\begin{array}{c}\text { Organophosphorus } \\
\text { insecticides }\end{array}$ & 11.460 & $\begin{array}{c}260.0-75.0(5)^{\mathrm{a}} \\
230.9-128.9(25)^{\mathrm{b}}\end{array}$ \\
\hline$\alpha-\mathrm{BHC}$ & $\mathrm{C}_{6} \mathrm{H}_{6} \mathrm{C}_{16}$ & $319-84-6$ & $\begin{array}{l}\text { Organochlorine } \\
\text { insecticides }\end{array}$ & 11.616 & $\begin{array}{l}218.8-146.6(20)^{\mathrm{a}} \\
218.8-183.0(8)^{\mathrm{b}}\end{array}$ \\
\hline Simazine & $\mathrm{C}_{7} \mathrm{H}_{12} \mathrm{ClN}_{5}$ & $122-34-9$ & Triazine herbicides & 12.033 & $\begin{array}{l}201.1-731.1(5)^{\mathrm{a}} \\
201.1-186.2(5)^{\mathrm{b}}\end{array}$ \\
\hline Atrazine & $\mathrm{C}_{8} \mathrm{H}_{14} \mathrm{ClN}_{5}$ & 1912-24-9 & Triazine herbicides & 12.034 & $\begin{array}{l}214.9-58.1(10)^{\mathrm{a}} \\
214.9-200.2(5)^{\mathrm{b}}\end{array}$ \\
\hline$\beta$-BHC & $\mathrm{C}_{6} \mathrm{H}_{6} \mathrm{Cl}_{6}$ & $319-85-7$ & $\begin{array}{l}\text { Organochlorine } \\
\text { insecticides }\end{array}$ & 12.099 & $\begin{array}{c}218.7-183.0(8)^{\mathrm{a}} \\
218.7-146.6(18)^{\mathrm{b}}\end{array}$ \\
\hline$\gamma$-BHC & $\mathrm{C}_{6} \mathrm{H}_{6} \mathrm{Cl}_{6}$ & 58-89-9 & $\begin{array}{c}\text { Organochlorine } \\
\text { insecticides }\end{array}$ & 12.280 & $\begin{array}{c}218.7-183.0(8)^{\mathrm{a}} \\
180.9-145.0(14)^{\mathrm{b}}\end{array}$ \\
\hline Terbufos & $\mathrm{C}_{9} \mathrm{H}_{21} \mathrm{O}_{2} \mathrm{PS}_{3}$ & 13071-79-9 & $\begin{array}{l}\text { Organophosphorus } \\
\text { insecticides }\end{array}$ & 12.300 & $\begin{array}{l}230.9-175.0(10)^{\mathrm{a}} \\
230.9-129.0(20)^{\mathrm{b}}\end{array}$ \\
\hline Isazophos & $\mathrm{C}_{9} \mathrm{H}_{17} \mathrm{ClN}_{3} \mathrm{O}_{3} \mathrm{PS}$ & $42509-80-8$ & $\begin{array}{c}\text { Organophosphorus } \\
\text { insecticides }\end{array}$ & 12.677 & $\begin{array}{l}161.0-119.0(5)^{\mathrm{a}} \\
161.0-146.0(5)^{\mathrm{b}}\end{array}$ \\
\hline$\delta$-BHC & $\mathrm{C}_{6} \mathrm{H}_{6} \mathrm{Cl}_{6}$ & $319-86-8$ & $\begin{array}{l}\text { Organochlorine } \\
\text { insecticides }\end{array}$ & 12.863 & $\begin{array}{l}218.8-146.5(20)^{\mathrm{a}} \\
218.8-182.9(8)^{\mathrm{b}}\end{array}$ \\
\hline $\begin{array}{l}\text { Parathion- } \\
\text { methyl }\end{array}$ & $\mathrm{C}_{8} \mathrm{H}_{10} \mathrm{NO}_{5} \mathrm{PS}$ & $298-00-0$ & $\begin{array}{l}\text { Organophosphorus } \\
\text { insecticides }\end{array}$ & 13.791 & $\begin{array}{l}262.9-109.0(10)^{\mathrm{a}} \\
232.9-109.0(10)^{\mathrm{b}}\end{array}$ \\
\hline Fenitrothion & $\mathrm{C}_{9} \mathrm{H}_{12} \mathrm{NO}_{6} \mathrm{P}$ & $2255-17-6$ & $\begin{array}{l}\text { Organophosphorus } \\
\text { insecticides }\end{array}$ & 14.404 & $\begin{array}{l}277.0-109.0(16)^{\mathrm{a}} \\
277.0-260.0(6)^{\mathrm{b}}\end{array}$ \\
\hline Chlorpyrifos & $\mathrm{C}_{9} \mathrm{H}_{11} \mathrm{Cl}_{3} \mathrm{NO}_{3} \mathrm{PS}$ & 2921-88-2 & $\begin{array}{l}\text { Organophosphorus } \\
\text { insecticides }\end{array}$ & 14.795 & $\begin{array}{l}196.9-169.0(15)^{\mathrm{a}} \\
198.9-171.0(15)^{\mathrm{b}}\end{array}$ \\
\hline Isocarbophos & $\mathrm{C}_{11} \mathrm{H}_{16} \mathrm{NO}_{4} \mathrm{PS}$ & $24353-61-5$ & $\begin{array}{l}\text { Organophosphorus } \\
\text { insecticides }\end{array}$ & 15.142 & $\begin{array}{l}135.9-108.0(15)^{\mathrm{a}} \\
135.9-69.0(30)^{\mathrm{b}}\end{array}$ \\
\hline Dicofol & $\mathrm{C}_{14} \mathrm{H}_{9} \mathrm{Cl}_{5} \mathrm{O}$ & $115-32-2$ & $\begin{array}{l}\text { Organochlorine } \\
\text { insecticides }\end{array}$ & 15.227 & $\begin{array}{l}250.9-139.0(12)^{\mathrm{a}} \\
139.0-111.0(12)^{\mathrm{b}}\end{array}$ \\
\hline Quinalphos & $\mathrm{C}_{12} \mathrm{H}_{15} \mathrm{~N}_{2} \mathrm{O}_{3} \mathrm{PS}$ & $13593-03-8$ & $\begin{array}{l}\text { Organophosphorus } \\
\text { insecticides }\end{array}$ & 16.178 & $\begin{array}{l}157.1-129.0(14)^{\mathrm{a}} \\
157.1-102.0(22)^{\mathrm{b}}\end{array}$ \\
\hline Phosfolan & $\mathrm{C}_{7} \mathrm{H}_{14} \mathrm{NO}_{3} \mathrm{PS}_{2}$ & $947-02-4$ & $\begin{array}{l}\text { Organophosphorus } \\
\text { insecticides }\end{array}$ & 16.376 & $\begin{array}{l}195.8-139.9(10)^{\mathrm{a}} \\
168.0-140.0(10)^{\mathrm{b}}\end{array}$ \\
\hline Endosulfan & $\mathrm{C}_{9} \mathrm{H}_{6} \mathrm{Cl}_{6} \mathrm{O}_{3} \mathrm{~S}$ & $115-29-7$ & $\begin{array}{c}\text { Organochlorine } \\
\text { insecticides }\end{array}$ & 17.144 & $\begin{array}{l}240.6-205.9(14)^{\mathrm{a}} \\
194.7-159.4(8)^{\mathrm{b}}\end{array}$ \\
\hline Profenofos & $\mathrm{C}_{11} \mathrm{H}_{15} \mathrm{BrClO}_{3} \mathrm{PS}$ & 41198-08-7 & $\begin{array}{l}\text { Organophosphorus } \\
\text { insecticides }\end{array}$ & 17.620 & $\begin{array}{c}207.9-63.0(30)^{\mathrm{a}} \\
338.8-268.7(15)^{\mathrm{b}}\end{array}$ \\
\hline
\end{tabular}




\begin{tabular}{|c|c|c|c|c|c|}
\hline p.p $\mathrm{p}^{\prime}-\mathrm{DDE}$ & $\mathrm{C}_{14} \mathrm{H}_{8} \mathrm{Cl}_{4}$ & $72-55-9$ & $\begin{array}{l}\text { Organochlorine } \\
\text { insecticides }\end{array}$ & 17.711 & $\begin{array}{l}317.8-246.0(20)^{\mathrm{a}} \\
317.8-248.0(18)^{\mathrm{b}}\end{array}$ \\
\hline Chlorfenapyr & $\begin{array}{c}\mathrm{C}_{15} \mathrm{H}_{11} \mathrm{BrClF}_{3} \mathrm{~N}_{2} \\
\mathrm{O}\end{array}$ & \begin{tabular}{|c|}
$122453-73-$ \\
0 \\
\end{tabular} & $\begin{array}{c}\text { Pyrrole insecticides, } \\
\text { acaricides }\end{array}$ & 18.238 & $\begin{array}{l}248.9-137.1(18)^{\mathrm{a}} \\
248.9-112.0(24)^{\mathrm{b}}\end{array}$ \\
\hline p.p ${ }^{\prime}-\mathrm{DDD}$ & $\mathrm{C}_{14} \mathrm{H}_{10} \mathrm{Cl}_{4}$ & $72-54-8$ & $\begin{array}{c}\text { Organochlorine } \\
\text { insecticides }\end{array}$ & 19.031 & $\begin{array}{l}235.0-199.0(14)^{\mathrm{a}} \\
235.0-165.1(20)^{\mathrm{b}}\end{array}$ \\
\hline o.p $\mathrm{p}^{\prime}-\mathrm{DDT}$ & $\mathrm{C}_{14} \mathrm{H}_{10} \mathrm{Cl}_{4}$ & $53-19-0$ & $\begin{array}{l}\text { Organochlorine } \\
\text { insecticides }\end{array}$ & 19.097 & $\begin{array}{l}235.0-199.0(14)^{\mathrm{a}} \\
235.0-165.1(20)^{\mathrm{b}}\end{array}$ \\
\hline p.p ${ }^{\prime}-\mathrm{DDT}$ & $\mathrm{C}_{14} \mathrm{H}_{10} \mathrm{Cl}_{4}$ & $72-54-8$ & $\begin{array}{l}\text { Organochlorine } \\
\text { insecticides }\end{array}$ & 20.247 & $\begin{array}{l}235.0-199.0(14)^{\mathrm{a}} \\
235.0-165.1(22)^{\mathrm{b}}\end{array}$ \\
\hline Bifenthrin & $\mathrm{C}_{23} \mathrm{H}_{22} \mathrm{ClF}_{3} \mathrm{O}_{2}$ & $82657-04-3$ & $\begin{array}{c}\text { Pyrethroid } \\
\text { insecticides }\end{array}$ & 21.920 & $\begin{array}{l}181.0-179.0(12)^{\mathrm{a}} \\
181.0-165.9(10)^{\mathrm{b}}\end{array}$ \\
\hline Etoxazole & $\mathrm{C}_{21} \mathrm{H}_{23} \mathrm{~F}_{2} \mathrm{NO}_{2}$ & \begin{tabular}{|c|}
$153233-91-$ \\
1 \\
\end{tabular} & Acaricide & 22.202 & $\begin{array}{c}141.0-113.0(15)^{\mathrm{a}} \\
141.0-63.1(30)^{\mathrm{b}} \\
\end{array}$ \\
\hline Fenpropathrin & $\mathrm{C}_{22} \mathrm{H}_{23} \mathrm{NO}_{3}$ & $39515-41-8$ & $\begin{array}{l}\text { Pyrethroid } \\
\text { insecticides }\end{array}$ & 22.239 & $\begin{array}{c}207.9-181.0(5)^{\mathrm{a}} \\
264.9-210.0(10)^{\mathrm{b}} \\
\end{array}$ \\
\hline Cyhalothrin & $\mathrm{C}_{23} \mathrm{H}_{19} \mathrm{ClF}_{3} \mathrm{NO}_{3}$ & $91465-08-6$ & $\begin{array}{l}\text { Pyrethroid } \\
\text { insecticides }\end{array}$ & 23.775 & $\begin{array}{c}197.1-141.1(10)^{\mathrm{a}} \\
197.1-161.1(5)^{\mathrm{b}} \\
\end{array}$ \\
\hline Pyridaben & $\mathrm{C}_{19} \mathrm{H}_{25} \mathrm{ClN}_{2} \mathrm{OS}$ & $96489-71-3$ & Acaricide & 25.472 & $\begin{array}{c}147.1-132.1(12)^{\mathrm{a}} \\
147.1-119.1(8)^{\mathrm{b}} \\
\end{array}$ \\
\hline Permethrin & $\mathrm{C}_{21} \mathrm{H}_{20} \mathrm{Cl}_{2} \mathrm{O}_{3}$ & $52645-53-1$ & $\begin{array}{l}\text { Pyrethroid } \\
\text { insecticides }\end{array}$ & 25.475 & $\begin{array}{l}183.0-168.1(10)^{\mathrm{a}} \\
183.0-153.1(10)^{\mathrm{b}} \\
\end{array}$ \\
\hline Cyfluthrin & $\mathrm{C}_{22} \mathrm{H}_{18} \mathrm{Cl}_{2} \mathrm{~F}_{2} \mathrm{NO}_{3}$ & $68359-37-5$ & $\begin{array}{l}\text { Pyrethroid } \\
\text { insecticides }\end{array}$ & 26.686 & $\begin{array}{l}226.0-206.0(15)^{\mathrm{a}} \\
198.9-170.1(25)^{\mathrm{b}} \\
\end{array}$ \\
\hline Cypermethrin & $\mathrm{C}_{22} \mathrm{H}_{19} \mathrm{Cl}_{2} \mathrm{NO}_{3}$ & $52315-07-8$ & $\begin{array}{l}\text { Pyrethroid } \\
\text { insecticides }\end{array}$ & 27.287 & $\begin{array}{l}163.0-127.0(6)^{\mathrm{a}} \\
163.0-91.0(10)^{\mathrm{b}} \\
\end{array}$ \\
\hline Flucythrinate & $\mathrm{C}_{26} \mathrm{H}_{23} \mathrm{~F}_{2} \mathrm{NO}_{4}$ & $70124-77-5$ & $\begin{array}{l}\text { Pyrethroid } \\
\text { insecticides }\end{array}$ & 27.609 & $\begin{array}{c}199.0-157.1(8)^{\mathrm{a}} \\
157.1-107.0(12)^{\mathrm{b}} \\
\end{array}$ \\
\hline Pyraclostrobin & $\mathrm{C}_{19} \mathrm{H}_{18} \mathrm{ClN}_{3} \mathrm{O}_{4}$ & \begin{tabular}{|c|}
$175013-18-$ \\
0 \\
\end{tabular} & Bactericide & 28.740 & $\begin{array}{l}116.0-89.0(15)^{\mathrm{a}} \\
116.0-63.0(30)^{\mathrm{b}}\end{array}$ \\
\hline Fenvalerate & $\mathrm{C}_{25} \mathrm{H}_{22} \mathrm{ClNO}_{3}$ & $51630-58-1$ & $\begin{array}{l}\text { Pyrethroid } \\
\text { insecticides }\end{array}$ & 28.951 & $\begin{array}{l}167.0-125.0(32)^{\mathrm{a}} \\
225.0-119.0(25)^{\mathrm{b}}\end{array}$ \\
\hline Difenoconazoie & $\mathrm{C}_{19} \mathrm{H}_{17} \mathrm{Cl}_{2} \mathrm{~N}_{3} \mathrm{O}_{3}$ & \begin{tabular}{|c|}
$119446-68-$ \\
3 \\
\end{tabular} & Bactericide & 29.504 & $\begin{array}{l}265.0-202.0(16)^{\mathrm{a}} \\
323.0-265.0(14)^{\mathrm{b}}\end{array}$ \\
\hline Deltamethrin & $\mathrm{C}_{22} \mathrm{H}_{19} \mathrm{Br}_{2} \mathrm{NO}_{3}$ & $52918-63-5$ & $\begin{array}{l}\text { Pyrethroid } \\
\text { insecticides }\end{array}$ & 29.886 & $\begin{array}{l}252.8-172.0(8)^{\mathrm{a}} \\
252.8-92.9(16)^{\mathrm{b}}\end{array}$ \\
\hline
\end{tabular}

${ }^{\mathrm{a}}$ Quantification ion

${ }^{\mathrm{b}}$ Confirmation ion

$\alpha$-BHC, $\beta$-BHC, $\gamma$-BHC and $\delta$-BHC are isomers of the hexachlorocyclohexane; p.p'-DDE, p.p'-DDD, o.p'-DDT and p.p'-DDT are isomers of the clofenotane

Abbreviations: CAS, Chemical Abstracts Service; MRM, Multiple Reaction Monitoring; $\alpha$-BHC, $\alpha-$ hexachlorocyclohexane; $\beta$-BHC, $\beta$-hexachlorocyclohexane; $\gamma$-BHC, $\gamma$-hexachlorocyclohexane; $\delta$-BHC, $\delta$-hexachlorocyclohexane; p.p'-DDE, 2-bis(4-chorophenyl)ethylene; p.p'-DDD, 1,1-Dichloro-2,2-bis(pchlorophenyl)ethane; p.p'-DDT, 2, 2-bis(4-chlorophenyl)-1,1,1-trichloroethane; o.p'-DDT, 1,1,1Trichloro-2-(2-chlorophenyl)-2-(4-chlorophenyl)ethane 